Original Research Paper

\title{
Financial and Social Inclusion and Financial Sector Development: An Outline in the EU28
}

\author{
${ }^{1}$ Domenica Federico, ${ }^{2}$ Maria Adele Milioli, ${ }^{1}$ Antonella Notte and ${ }^{2}$ Lucia Poletti \\ ${ }^{1}$ Faculty of Economics, e-Campus University, Italy \\ ${ }^{2}$ Department of Economics and Management, University of Parma, Italy
}

\section{Article history}

Received: 17-10-2019

Revised: 19-11-2019

Accepted: 13-01-2020

Corresponding Author: Domenica Federico Faculty of Economics, eCampus University, Italy Email: domenica.federico@uniecampus.it

\begin{abstract}
The paper describes the status of the European Union member countries, from the point of view of both financial and social inclusion and the development of the financial sector. The aim is to identify clusters of countries, with internally homogeneous but externally heterogeneous characteristics. The analysis shows if social exclusion and financial exclusion coexist in the same countries, considering the development of the financial sector. From a methodological point of view, the research collects and analyzes data extrapolated from different sources in the period 2016-2017 and it is conducted through a Principal Component Analysis and a Cluster Analysis.
\end{abstract}

Keywords: Financial Inclusion, Social Inclusion, Financial Sector, Multivariate Statistical Analysis, EU28

\section{Introduction}

Financial inclusion has emerged as an important issue on the global policy agenda for sustainable development due to its contribution to the economic development of a country. An inclusive financial system ensures efficient allocation of productive resources and thereby reduces the cost of capital and need for informal sources of credit.

Some central banks have introduced schemes to improve financial inclusion in their countries and an increasing number of frontrunners [e.g., International Finance Corporation (IFC), International Monetary Fund (IMF), Group of Twenty (G20), Alliance for Financial Inclusion (AFI) and Consultative Group to Assist the Poor (CGAP)] are also playing an active role internationally.

Social inclusion too has become central to policy and to academic discourse in Europe. The concept is widely used and appears to be very attractive to the producers of social policy discourse.

The literature focuses on understanding to what extent financial system development leads to financial and social inclusion. There is a consensus that financial sector development contributes indirectly to poverty reduction through economic growth. Higher growth benefits the poor by creating more jobs, enabling the government to allocate more fiscal resources on social spending and increasing funds available to the poor for investment.
It is widely agreed that financial sector development directly also supports poverty reduction by broadening the access to finance of the poor and vulnerable groups. The financial system facilitates transactions thus reducing their costs, provides the opportunity to accumulate assets and enables poor households to better cope with shocks, thus mitigating the risk of poverty.

It is thus clear why the European Union encourages the development of initiatives such as microfinance schemes focused on financial and social inclusion, job creation and economic growth in general. For example, in many European countries, microfinance is gradually being consolidated as an essential social policy tool for the promotion of self-employment, microenterprise support and the fight against social and financial exclusion.

The paper investigates the phenomenon of financial and social inclusion and financial sector development in European Union member countries (EU28). The aim is to describe the status of the EU28 countries, from the point of view of both financial and social inclusion and the development of the financial sector regarding in particular banking intermediation, in order to identify clusters, with internally homogeneous but externally heterogeneous characteristics. The analysis aims at showing if social exclusion and financial exclusion coexist in the same countries, taking into account the development of the financial sector. 
Methodologically, the research collects and analyzes data extrapolated from different sources in the period 2016-2017. It is conducted through a Principal Component Analysis (ACP), which outlines relationships between the different dimensions of the phenomena (formal financial inclusion, social inclusion and development of financial sector) and a Cluster Analysis which classifies a set of units into groups with the characteristics of internal cohesion (the units in the same cluster must be similar to each other) and external separation (the clusters must be as distinct as possible).

\section{Literature on Definitions and Measures}

We describe in this section the literature on definitions and measures of financial and social inclusion.

\section{Financial Inclusion}

The concept of financial inclusion is complex and multifaceted. It is being constantly developed in academic discourse and EU policy though there is no global definition of financial inclusion.

In the most common and very generic form, financial inclusion is defined "as the process of ensuring affordable, prompt and adequate access to a wide range of financial products and services, as well as proliferation of their use in all parts of society with a special focus on vulnerable groups, thought the implementation of existing and innovative approaches, such as financial literacy programmes" (Gortsos, 2016: 10).

Conversely, the opposite of financial inclusion i.e. financial exclusion, can be defined as the impossibility or reluctance of individuals or businesses to access basic financial services such as current and deposit accounts, loans, insurance services and of payment (Gortsos, 2016).

Existing literature on financial inclusion (or financial exclusion) uses varying definitions. Many studies define the concept in terms of financial exclusion, which relates to the broader context of social inclusion while others define financial inclusion. Both concepts are closely intertwined.

In literature, financial inclusion (or exclusion) have been described by national and international literature since the 1990s (Table 1).

Early literature on financial exclusion concentrated on issues of geographical access to services, particularly bank branches and tended to use a narrow view in terms of "access".

Leyshon and Thrift (1995: 314) define financial exclusion as "processes that serve to prevent certain social groups and individuals from gaining access to the financial system".

There is a general consensus that financial exclusion is primarily concerned with the lack of a bank account, particularly a current account. There are different degrees of financial exclusion, reflecting the availability of financial products and services widely available, their accessibility, appropriateness to the needs of individuals and the proper management of the same. Kempson and Whyley $(1999$, p. 3) argue that exclusion may relate to those including those "who are refused all products, those who decide freely not to use them and those who self-exclude because of the inappropriateness of current products to households in their financial circumstances".

Kempson et al. (2000) recognize that financial exclusion is complex and multi-dimensional and can come about as a result of a range of problems with access, conditions, price, marketing or self-exclusion. In particular, Kempson et al. (2000: 9) identify " a number of other dimensions of financial exclusion:

1. Access exclusion: the restriction of access through the processes of risk assessment

2. Condition exclusion: Where the conditions attached to financial products make them inappropriate for the needs of some people

3. Price exclusion: where some people can only gain access to financial products at prices they cannot afford

4. Marketing exclusion: Whereby some people are effectively excluded by targeting marketing and sales

5. Self-exclusion: People may decide that there is little point applying for a financial product because they believe they would be refused. Sometimes this is a result of having been refused personally in the past, sometimes because they know someone else who has been refused, or because of a belief that they don't accept people who live round here

According to Sinclair (2001), financial exclusion means the inability to access necessary financial services in an appropriate form. Exclusion can be a result of problems with access, conditions, prices, marketing, or self-exclusion in response to negative experiences or perceptions.

Gloukoviezoff (2004) on the other hand finds that "access" is only part of the problem and that the greatest challenge lies in difficulties in "using" financial services. He defines financial exclusion as the process by which a person encounters such difficulties in accessing and/or using its banking practices that he/she is no longer able to have a normal social life in society.

The literature shows several degrees of financial exclusion, depending on the level of complexity of the services used and/or the use of unofficial suppliers. In particular, World Bank (2005) distinguishes between "formally served" and "financially served" and considers "financially excluded" only those who have no kind of access. 
Table 1: Resume of literature on financial inclusion/exclusion definition

\begin{tabular}{|c|c|c|}
\hline & Definition & Principal Authors \\
\hline & Financial inclusion & $\begin{array}{l}\text { Amidžić et al. (2014; Hanning and Jansen, 2010; Kempson and } \\
\text { Collard, 2012; OECD 2013; Sarma, 2012; UNCDF, 2006) }\end{array}$ \\
\hline By concept & Financial exclusion & $\begin{array}{l}\text { Carbo et al. (2005; Conroy, 2005; European Commission, } \\
\text { 2008; Gloukoviezoff, 2004; Kempson and Whyley, 1999; } \\
\text { Kempson et al., 2000; Leyshon and Thrift, 1995; Mohan, } \\
\text { 2006; Sinclair, 2001; World Bank, 2005) }\end{array}$ \\
\hline $\begin{array}{l}\text { By principal elements } \\
\text { in the definition }\end{array}$ & $\begin{array}{l}\text { Inability to "access" to formal } \\
\text { financial system }\end{array}$ & $\begin{array}{l}\text { Leyshon and Thrift (1995; Sinclair, 2001; World Bank, 2005; } \\
\text { Carbo et al., 2005; Conroy, 2005; Mohan, 2006; UNCDF, 2006) }\end{array}$ \\
\hline & $\begin{array}{l}\text { Difficulty to "access and/or use" of } \\
\text { basic financial services and products }\end{array}$ & $\begin{array}{l}\text { Amidžić et al. (2014; Gloukoviezoff, 2004; European Commission, } \\
\text { 2008; Hanning and Jansen, 2010; Kempson and Whyley, 1999; } \\
\text { Kempson et al., 2000; OECD, 2013; Sarma, 2012) }\end{array}$ \\
\hline $\begin{array}{l}\text { By principal services } \\
\text { and products }\end{array}$ & $\begin{array}{l}\text { Lack of a bank account Lack of access } \\
\text { to affordable credit, savings and home } \\
\text { contents insurance }\end{array}$ & $\begin{array}{l}\text { Kempson et al. (2000; European Commission, 2008; } \\
\text { Hanning and Jansen, 2010) }\end{array}$ \\
\hline
\end{tabular}

Carbo et al. (2005) and Conroy (2005) define financial exclusion as a process that prevents poor and disadvantaged social groups accessing the formal financial system.

According to Mohan (2006: 5) financial exclusion signifies the lack of access by certain segments of the society to appropriate, low-cost, fair and safe financial products and services from mainstream providers.

The goals of financial inclusion are defined by UNCDF (2006) as access for all households to a full range of financial services at reasonable cost; safe institutions governed by clear regulation; financial and institutional sustainability that ensure certainty of investment; competition to ensure choice and affordability for clients.

European Commission (2008: 9) defines financial exclusion as "a process whereby people encounter difficulties accessing and/or using financial services and products in the mainstream market that are appropriate to their needs and enable them to lead a normal social life in the society in which they belong". It distinguishes four forms of financial exclusion: exclusion from basic banking services, exclusion of credit, exclusion from services and savings products and exclusion from access to insurance and social security services.

According to Hanning and Jansen (2010) financial inclusion does not imply that everyone should make use of products and banking services, or that providers should not consider risks and costs when offering services. They argue that "initiatives should aim to correct market failures and to eliminate nonmarket barriers to accessing a broad range of financial services".

Sarma (2012) defines financial inclusion through several dimensions; accessibility, availability and usage of the formal financial system.

Kempson and Collard (2012: 14), on the other hand write that "a financially inclusive society would be one in which everyone had the ability to manage day-to-day financial transactions, meet one-off expenses; manage a loss of earned income; avoid/reduce problem debt".

According to OECD (2013: 71) "financial inclusion refers to the process of promoting affordable, timely and adequate access to a range of regulated financial products and services and broadening their use by all segments of society through the implementation of tailored existing and innovative approaches including financial awareness and education with a view to promote financial wellbeing as well as economic and social inclusion".

World Bank (2014) distinguishes between voluntary versus involuntary exclusion. Voluntary exclusion is a condition where the segment of the population or firms choose not to use financial services either because they have no need for them or for cultural or religious reasons. Involuntary exclusion arises from insufficient income and high-risk profile or because of discrimination and market failures and imperfections. Policy and research initiatives should thus focus on involuntary exclusion, as it can be addressed by appropriate economic programs and policies which can be designed to increase income levels and correct market failures and imperfections.

Amidžić et al. (2014) state that financial inclusion is an economic state where individuals and firms are not denied access to basic financial services.

It is important to note the main measurements of financial inclusion as used by institutions running surveys collecting key indicators.

In particular, World Bank identifies the following indicators to measure financial exclusion:

1. Access indicators reflect the depth of outreach of financial services, such as the penetration of bank branches or Point Of Sale (POS) devices in rural areas and demand-side barriers that customers face to access financial institutions, such as cost or information

2. Usage indicators measure how clients use financial services, such as the regularity and duration of the 
financial product/service over time (e.g., average savings balances, number of transactions per account, number of electronic payments made)

3. Quality measures describe whether financial products and services match clients' needs, the range of options available to customers and clients' awareness and understanding of financial products

The main surveys providing data to measure financial exclusion are shown in Table 2.

The literature also focuses on the measurement of financial inclusion (Table 3).

Most studies on financial inclusion use country-level indicators to measure the extent of financial inclusion.

In particular, Honohan (2008) measures financial inclusion by simply measuring the proportion of adult population/households (of an economy) having a bank account. The composite financial access indicator is constructed using household survey data for economies with available data on financial access.

Sarma (2008) investigates macro level factors that can be associated with financial inclusion. The index of financial inclusion:

- Is constructed as a multidimensional index that captures information on various aspects of financial inclusion such as banking penetration (number of bank A/C per 1000 population), availability of banking services (number of bank branches and number of ATMs per 100,000 people) and usage of the banking system (volume of credit plus deposit relative to the GDP)

- Incorporates information on these dimensions in one single number lying between 0 and 1 , where 0 denotes complete financial exclusion and 1 indicates complete financial inclusion in an economy

Table 2: Survey on financial exclusion

\begin{tabular}{|c|c|c|c|}
\hline Supply-side data & & & Demand-side data \\
\hline $\begin{array}{l}\text { IMF Financial } \\
\text { Access Survey } \\
\text { (FAS) }\end{array}$ & $\begin{array}{l}\text { Penetration and usage of } \\
\text { financial services collected }\end{array}$ & Global findex & $\begin{array}{l}\text { Ownership of accounts; payments; saving, } \\
\text { credit and financial resilience; opportunities } \\
\text { for expanding financial inclusion }\end{array}$ \\
\hline BankScope & $\begin{array}{l}\text { Information on public and } \\
\text { private banks; detailed } \\
\text { balance sheet by bank; } \\
\text { income statements by bank }\end{array}$ & $\begin{array}{l}\text { Enterprise surveys } \\
\text { (World Bank) }\end{array}$ & $\begin{array}{l}\text { Access to finance; inadequately educated } \\
\text { workforce; practices of the informal sector; } \\
\text { bribery incidence (percent of firms experiencing } \\
\text { at least one bribe payment request); etc., }\end{array}$ \\
\hline $\begin{array}{l}\text { IMF-International } \\
\text { Financial Statistics } \\
\text { (IFS) }\end{array}$ & $\begin{array}{l}\text { GDP growth, inflation, } \\
\text { unemployment, payments } \\
\text { balances, exports, imports, } \\
\text { external debt, capital flows, } \\
\text { commodity prices }\end{array}$ & $\begin{array}{l}\text { Living Standards } \\
\text { Measurement } \\
\text { Study (LSMS) }\end{array}$ & $\begin{array}{l}\text { Access to financial services available; } \\
\text { usage of financial services available }\end{array}$ \\
\hline $\begin{array}{l}\text { IMF Financial } \\
\text { Soundness } \\
\text { Indicators (FSI) }\end{array}$ & $\begin{array}{l}\text { Financial soundness; } \\
\text { strengths of financial } \\
\text { systems; vulnerabilities } \\
\text { of financial systems }\end{array}$ & MECOVI & $\begin{array}{l}\text { Living conditions of people in the region, } \\
\text { in terms of scope, coverage, reliability, } \\
\text { timeliness and policy relevance }\end{array}$ \\
\hline FinStats & $\begin{array}{l}\text { Equities; fund prices; currencies, } \\
\text { dividends and indices }\end{array}$ & Financial Diaries & Financial management in poor households \\
\hline
\end{tabular}

Table 3: Resume of literature on measurement financial exclusion definition

\begin{tabular}{ll}
\hline Indicators & Principal Authors \\
\hline $\begin{array}{l}\text { Indicators that combine both household survey datasets and published } \\
\text { financial institution data }\end{array}$ & Honohan (2008; Rojas-Suarez, 2010) \\
$\begin{array}{l}\text { Number of bank A/C per } 1000 \text { population; number of bank branches; } \\
\text { number of ATMs per 100,000 people; volume of credit plus deposit } \\
\text { relative to the GDP }\end{array}$ & Chakravarty and Pal (2010; Korynski, \\
$\begin{array}{l}\text { Number of ATMs per 1,000 square kilometers; number of branches of } \\
\text { ODCs per 1,000 square kilometers; total number of resident household } \\
\text { depositors with ODCs per 1,000 adults; total number of resident } \\
\text { household borrowers with ODCs per 1,000 adults }\end{array}$ & Amidžić et al. (2014) \\
$\begin{array}{l}\text { Accounts; loans; savings; ATMs per 100,000 people; branches per } \\
100,000 \text { people; ATMs per 1,000 square kilometers; branches per }\end{array}$ & \\
1,000 square kilometers; distance; affordability; documentation; lack of trust & \\
\hline
\end{tabular}


Mehrotra et al. (2009) build up an index for financial inclusion using similar aggregate indicators like number of rural offices, number of rural deposit accounts, volume of rural deposit and credit from banking data for sixteen large states of India. They propose a financial inclusion index that is computed as a weighted arithmetical average of the various dimensions of financial inclusion.

Rojas-Suarez (2010) uses the indicator constructed by Honohan (2008) to test the significance of various macroeconomic and country characteristics for a group of emerging economies, including some from developing Asia. The results show that economic volatility, weak rule of law, higher income inequality and social underdevelopment and regulatory constraints significantly lower financial access. In addition, various country grouping dummy variables are also found to be significant especially for large emerging economies.

Chakravarty and Pal (2010) employ the axiomatic measurement approach developed in the human development literature to the measurement of financial inclusion. They improve upon the IFI proposed by Sarma (2008) so that the index can be utilized to determine percentage contributions made by various factors.

Kumar Kuri and Laha (2011) identify the underlying factors that are responsible for creating obstacles in the process of financial inclusion in rural West Bengal. In particular, they use a Binary Probit Regression Model and identify the greater degree of awareness of basic banking services, diversification in the rural non-farm sector, literacy drive to rural households and an expansion of household level asset as factors crucial to create an enabling environment which reduces obstacles to financial inclusion.

Singh and Kodan (2012) identify factors associated with financial inclusion with the help of Regression Analysis and find that financial inclusion is significantly positively associated with socio-economic development. They find that per capita Net State Domestic Product (NSDP) and urbanization are significant predictors of financial inclusion, while literacy, employment and sexratio are not statistically significant predictors.

Likewise, Johnson and Nino-Zarazua (2011) examine the patterns of access and socio-economic, geographic and demographic variables associated with access to finance in Kenya and Uganda. They find that age, employment, education and gender are key factors explaining access to formal financial services and also show that an informal financial sector contributes substantially to access to finance.

Korynski (2013) uses Sarma's methodology to calculate the financial inclusion score for Belarus and proposes several versions of the index with different weights for each dimension.

Kumar (2013) evaluates the determinants of financial inclusion in India and shows that branch density, the level of industrialization and the prevalence of an employee base have a beneficial impact on financial inclusion. He uses number of branches, number of credit accounts, credit amounts outstanding, number of deposit accounts, deposit amount, number of factories, population and employment.

Amidžić et al. (2014) construct a financial inclusion indicator as a composite indicator of variables pertaining to dimension, outreach (geographic and demographic penetration), usage (deposit and lending) and quality (disclosure requirement, dispute resolution and cost of usage).

Cámara and Tuesta (2014) use a Principal Component Analysis (PCA) and find that access and usage are both necessary but not sufficient conditions for measuring the inclusiveness of a financial system. They show that focus on usage and access to the detriment of other factors leads to limited measurement of financial inclusion. They find that the degree of financial inclusion is determined by three parameters: Usage (people who have a bank account, people who use mobile banking services but do not have an account and people who have a credit or debit card but do not have an account), barriers (distance, lack of the necessary documentation, affordability and lack of trust in the formal financial system) and access (ATMs, commercial bank branches).

Demirgüç-Kunt et al. (2015) measure financial inclusion on the basis of 3 parameters: level of credit institution outreach (number of branches per square kilometer, the number of ATM per square kilometer, the number of branches per one thousand individuals), level of usage of financial products and services (percentages of loans and deposit account in the population, number of transactions per deposit account, number of electronic payments) and quality of the products and services (cost of usage, level of financial literacy).

Sarma (2015) proposes a measure of inclusiveness of a financial system that incorporates information on various aspects of financial inclusion including banking penetration, availability and usage.

Finaccess (2016) provides measurement of financial inclusion (access, usage, quality and impact) in Kenya. Measures include level of formality (access strand), choice of institution (e.g., bank, informal group, SACCOS) and functionality (e.g., savings, credit and insurance).

Sathiyan and Panda (2016) analyze the determinants of financial inclusion in India during the post-reform period using a multiple regression model. They suggest that financial inclusion is determined by factors such as the number of bank branches, population dependency per branch and industry concentration in the state, while socioeconomic factors like per-capita income of the state, literacy rates and urbanization are not significant factors. 
Ampudia and Ehrmann (2017) study the determinants of being 'unbanked' in the euro area and the United States. They document that low-income households, unemployed households and those with a poor education are the most likely to be affected and significantly more so in the United States than in the euro area.

\section{Social Inclusion}

Social inclusion (or social exclusion) figured prominently in policy discourse in France in the mid 1970s, partly in response to massive economic restructuring that began to affect labour markets, social policies, poverty and migration flows.

The concept was also used in other industrialized countries and was adopted by the EU in the late 1980s as a key concept in social policy. In many instances it replaced the concept of poverty.

The EU defines social exclusion as a process through which people are wholly or partially excluded from full participation in the society in which they live (Deakin et al., 1995).

Social inclusion is a priority item of the European Agenda, 2020 which aims to ensure economic, social and territorial cohesion by guaranteeing respect for the fundamental rights of people experiencing social exclusion, so that they can live in dignity and take an active part in society.

The European Union (2004: 10) defines social inclusion and social exclusion as follows:

- Social inclusion is a process which ensures that those at risk of poverty and social exclusion gain the opportunities and resources necessary to participate fully in economic, social and cultural life and to enjoy a standard of living and well-being that is considered normal in the society in which they live. It ensures that they have a greater participation in decision making which affects their lives and access to their fundamental rights

- Social exclusion is a process whereby certain individuals are pushed to the edge of society and prevented from participating fully by virtue of their poverty, or lack of basic competencies and lifelong learning opportunities, or as a result of discrimination. This distances them from job, income and education opportunities as well as social and community networks and activities. They have little access to power and decisionmaking bodies and thus often feeling powerless and unable to take control over the decisions that affect their day to day lives

A European Commission (2011) report focuses on social inclusion and poverty reduction and defines three indicators which reflect the multiple facets of poverty and exclusion across Europe. These are the at-risk-of poverty rate, severe material deprivation and people living in households with very low work intensity.

Social inclusion is a multidimensional phenomenon that involves social, psychological, political and economic aspects of an individual's life (Atkinson et al., 2002; Bossert et al., 2007; Chakravarty and D'Ambrosio, 2006). The literature is diverse and extensive and there are numerous definitions of social exclusion and social inclusion (Table 4).

The definitions of social inclusion and social exclusion vary significantly depending on the context and have continually evolved over time.

In fact, a variety of terms are used interchangeably in both research and policy documents, including solidarity, integration, cohesion and social capital (Beauvais and Jenson, 2002; Berger, 1998; Bernard, 1999; Brunkhorst and Flynn, 2005; Daly and Silver, 2008; Kymlicka, 2010; Putnam, 2007; Silver, 1994). For example, Goodin (1996) considers participation as the antidote to social exclusion, while Woodward and Kohli (2001), shows that social inclusion is located in a theoretical context of social integration and institutions of social membership.

United Nations (1995: 68) stresses the connection of social inclusion to social integration or social cohesion, presenting a vision for " $a$ society for all, in which every individual, each with rights and responsibilities, has an active role to play".

According to Burchardt et al. (1999), social exclusion is associated with failures in achieving a reasonable living standard, a degree of security, an activity valued by others, some decision-making power and the possibility of drawing support from relatives and friends.

Toye and Infanti (2004) find that social inclusion is about a strategy for change and a vision for improving people's conditions.

Daly (2006) also notes that social inclusion is often discussed interchangeably with social exclusion without any systematic working out of why inclusion should be the solution to exclusion.

According to Hickey and du Toit (2007), the concept of social exclusion is used in industrialized countries to describe the processes of marginalization and deprivation which can arise where processes of economic and social transformation render 'traditional' systems of welfare and social protection inadequate or obsolete. Social exclusion is not coterminous with poverty (i.e., it is possible to be 'excluded' without being poor), but many poor people are 'excluded'; and paying attention to exclusion allows a broader view of deprivation and disadvantage than the somewhat narrower concept of 'poverty'. 
Table 4: Resume of literature on social exclusion/inclusion definition

\begin{tabular}{|c|c|c|}
\hline & Definition & Principal Authors \\
\hline & Social exclusion & $\begin{array}{l}\text { Burchardt et al. (1999; Deakin et al., 1995; European Union, 2004; } \\
\text { Hickey and du Toit, 2007) }\end{array}$ \\
\hline \multirow[t]{2}{*}{ By concept } & Social inclusion & $\begin{array}{l}\text { Atkison and Marlier (2010; Dugarova, 2015; European Union, 2004; } \\
\text { Frazer and Marlier, 2013; Hall, 2010; Quinn and Doyle, 2012; } \\
\text { Simplican } \text { et al., 2015; Walker } \text { et al., 2011; World Bank, 2013) }\end{array}$ \\
\hline & Poverty and exclusion & $\begin{array}{l}\text { Daly (2006; European Commission, 2011; Ghosh, 2010; Hall, 2009; } \\
\text { Toye and Infanti, 2004) }\end{array}$ \\
\hline \multirow[t]{2}{*}{$\begin{array}{l}\text { By principal elements } \\
\text { in the definition }\end{array}$} & $\begin{array}{l}\text { Solidarity, integration, } \\
\text { cohesion, social capital, } \\
\text { belonging }\end{array}$ & $\begin{array}{l}\text { Beauvais and Jenson (2002; Berger, 1998; Bernard, 1999; Brunkhorst and } \\
\text { Flynn, 2005; Daly and Silver, 2008; Dugarova and Lavers, 2014; Goodin, } \\
\text { 1996; Kymlicka, 2010; Power, 2013; Putnam, 2007; Silver, 2015; 1994; } \\
\text { United Nations, 1995; Verdonschot et al., 2009; Woodward and Kohli, 2001) }\end{array}$ \\
\hline & $\begin{array}{l}\text { Multidimensional } \\
\text { phenomenon }\end{array}$ & $\begin{array}{l}\text { Atkinson et al. (2002; Bossert et al., 2007; Chakravarty and D'Ambrosio, } \\
\text { 2006; Duggan and Linehan, 2013; Hospes and Clancy, 2011) }\end{array}$ \\
\hline
\end{tabular}

Focusing on people with severe and profound intellectual disability, Clement and Bigby (2009: 266) follow a narrow definition of social inclusion when they aim to "expand people's social networks by facilitating relationships with people who are not staff members, relatives, or people with intellectual disabilities". They narrow the scope in two ways: First, they exclude relationships with certain groups (staff, families and people with ID) and second, they discount community activities as a component of social inclusion, although they presume that relationships with community members would encompass community involvement.

Verdonschot et al. (2009) find that social inclusion can become interchangeable with social capital, when the definition of social inclusion includes benefits like increased trust, reciprocity and personal efficacy that may result from social networks and community involvement.

Social inclusion has also been defined as the endpoint for overcoming social exclusion, where social exclusion is characterized by the "involuntary exclusion of individuals and groups from society's political, economic and societal processes, which prevents their full participation in the society in which they live" (Atkison and Marlier, 2010).

Hall (2010) shows that when definitions of social inclusion encompass subjective feelings of belonging, value and acceptance, then social inclusion becomes interchangeable with a sense of belonging. So he argues that social inclusion without a sense of belonging misses the fact that social inclusion in mainstream settings may decrease a person's quality of life.

In the same year, Ghosh (2010) shows that poverty reduction does not automatically lead to social inclusion, as has been in the case in large emerging countries such as China and India, where poverty has drastically fallen in recent years while inequalities and exclusion of some groups has increased.
Hospes and Clancy (2011) show that many impoverished and exploited people can be considered included, but on highly adverse terms and therefore social inclusion may not be automatically beneficial or necessary for the poor.

A particular definition is proposed by Walker et al. (2011: 7) that explain social inclusion of certain groups as "societal acceptance of people with disabilities within school, work and community settings".

Similarly, Cobigo et al. (2012) define social inclusion with significant depth emphasizing that individuals must have a sense of belonging in a social network, have experience of a valued social role and that be trusted to perform that social role in the community.

Quinn and Doyle (2012: 15) argue that "independent living and social inclusion are interrelated and that the Convention on the Rights of Persons with Disabilities promotes independent living through the enhancing of social connectedness".

A clear definition of social inclusion can help standardize the multiple ways that researchers measure social inclusion (Amado et al., 2013), while Duggan and Linehan (2013) argue that the concept of social inclusion has become interchangeable with independent living.

According to Frazer and Marlier (2013) social inclusion has been defined as a process in which those at risk of poverty and social exclusion gain the opportunities and resources that are needed to fully participate in societal activities. In this process, adequate income and employment have been treated as key means to tackle social exclusion, poverty and inequality.

Power (2013) tries to explain the social inclusion with regard to the concept of belonging. Particularly, he argued that belonging does not solely involve being placed within an environment, but fitting in within a specified place or environments.

According to World Bank (2013) social inclusion has also been seen as a foundation for shared prosperity that 
characterizes the process of improving abilities, opportunities and dignity of the disadvantaged through access to markets, services and spaces.

The World Bank Group defines social inclusion as:

1. The process of improving the terms for individuals and groups to take part in society

2. The process of improving the ability, opportunity and dignity of those disadvantaged on the basis of their identity to take part in society

According to Dugarova and Lavers (2014) social policy should be concerned not only with the welfare and rights of an individual but also with supporting social relations, institutions and structures through which the welfare of individuals in their households, communities and nations could be maintained and enhanced, while recognizing the importance of societal levels of analysis and not simply economic or individual indicators.

Dugarova (2015) considers social inclusion a goal (to achieve an inclusive society), a process (to enable persons' participation in decision-making activities that affect their lives) and an outcome (to ensure the reduction of inequalities and of any forms of discrimination).

A study by Simplican et al. (2015) lists definitions of social inclusion found in the literature in the last 10 years. Simplican et al. (2015) define social inclusion as the interaction between two major life domains or the interpersonal relationships and the community participation. These two concepts emerge as common themes, but conceptual differences emerge around the scope, setting and depth of social inclusion. They propose an ecological model of social inclusion that includes individual, interpersonal, organizational, community and socio-political factors. They identify four areas of research: organizational implementation of social inclusion; social inclusion of people with intellectual and developmental disabilities living with their families; social inclusion of people along a broader spectrum of disability; the potential role of self-advocacy organizations in promoting social inclusion.

Silver (2015) shows that social inclusion may involve a process of encouraging social interaction between people with different socially relevant attributes and demonstrates how contexts influence processes of economic, social and political exclusion and inclusion.

There are various measurements of social exclusion used by different institutions (Table 5).

In particular, a 2007 World Bank study (2007) contributes to the on-going dialogue on social inclusion in the new member states of Europe, by furthering analysis on the dimensions of exclusion and the policy instruments for supporting inclusion. It uses the definitions of social inclusion and social exclusion given by the EU (2004) and adopted as part of the EU's Lisbon process, in order to ensure consistency in terminology and with the EU28 objectives. The World Bank study (2007) derives an approach to quantifying the determinants of social exclusion in order to complement the analysis of poverty. The framework has at its center the concept of capability deprivation, which says that due to social and economic factors certain individuals in society may never reach their full potential. Four forms of capital are measured that can affect an individual's well being, economic fortunes, poverty and inclusion. These forms are financial, physical, capital and social capital.

United Nations (2010) demonstrates the analytical and operational relevance of the measurement of poverty and social exclusion, describing how such measures could be put in place and how there are different important dimensions of social exclusion, which encompasses a broader (complex and multi-dimensional) set of concerns. In this study (United Nations 2010) social exclusion is defined as the involuntary exclusion of individuals and groups from society's political, economic and societal processes, which prevents their full participation in the society in which they live. But the UN study does not identify a single set of indicators: the choice of indicators depends on the country context and on the purpose for which the indicators are to be used.

A Eurostat (2013) study on the measurement of poverty and social inclusion in Europe and reports that different indicators exist to measure social inclusion, including poverty, material deprivation and exclusion from the labour market, etc.. In particular, the EU is not at all homogeneous and particular indicators do not match needs and situations of all countries.

Numerous authors are also involved in studying the measurement of social exclusion (Table 6).

As noted above, social exclusion is a complex concept that encompasses interlinked problems and affects people or areas. In fact, people can be socially excluded, for example, by poverty, or by age or disability, even if they live in prosperous communities.

There are different approaches to measuring social exclusion. Most approaches focus on people rather than geographic areas and some attempt to include measures that take account of people's societal exclusion or isolation.

Analysis of social exclusion quantifies different dimensions beyond income poverty, including access to financial, physical, human and social capital. The concept can be used in multisectoral policy approaches that may not emerge through a focus solely on income or consumption based poverty measures. In fact, being poor can lead to exclusion, but exclusion is more than just being poor, it is about participation social and economic interactions. 
Table 5: Resume on measurements social exclusion/inclusion definition

\begin{tabular}{ll}
\hline Indicators & Principal Institutions \\
\hline Financial Capital, physical capital, human capital, social capital & World Bank (2007) \\
The choice of indicators depends on the country context and on the purpose & United Nations (2010) \\
for which the indicators are to be employed. & Eurostat (2013) \\
At-risk-of poverty rate, material deprivation, exclusion of labour market component & \\
\hline
\end{tabular}

Table 6: Resume of Literature on Measurements Social Exclusion/Inclusion Definition

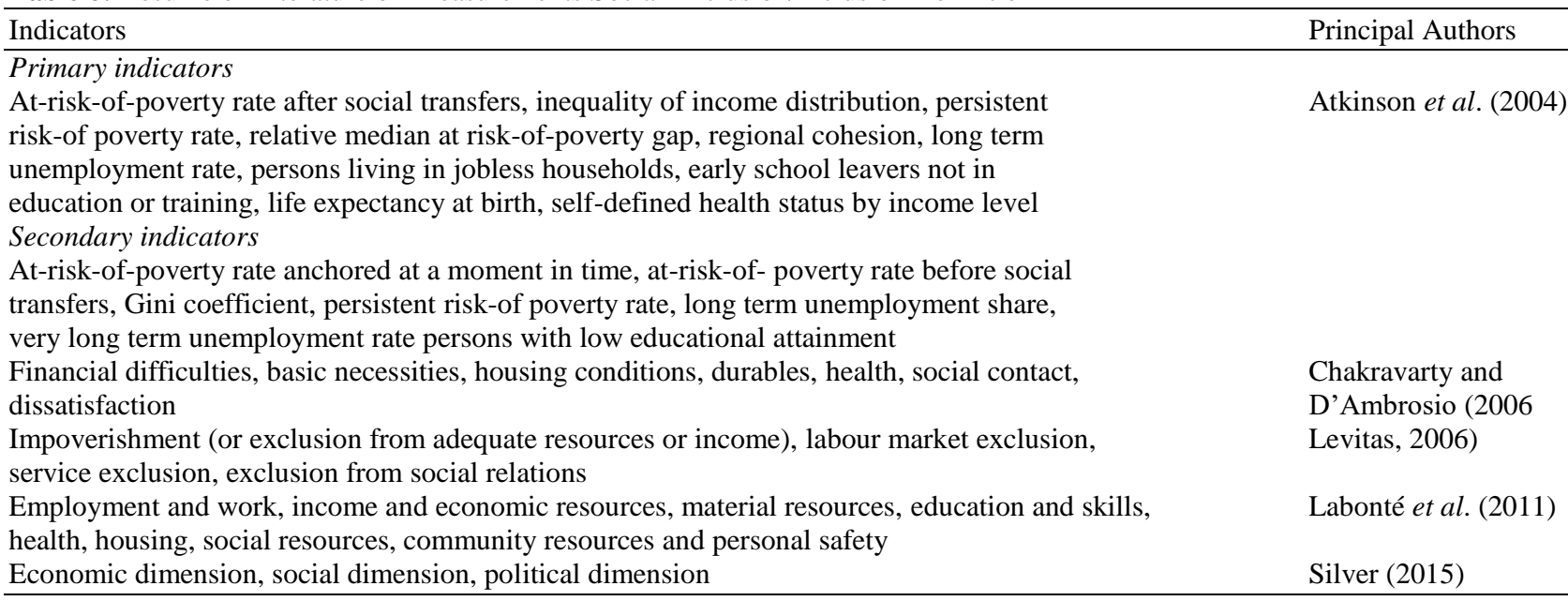

While income poverty and social exclusion overlap, they do not necessarily intersect. One can be socially excluded without being poor (Atkinson, 1998).

Some authors show that dimensions of exclusion are not necessarily related; their association also varies across national contexts (Muffels and Fouage, 2001; Pantazis et al., 2006; Tsakloglou and Papadopoulos, 2002).

Another paper by Atkinson et al. (2004) reviews the scientific and political basis on which the indicators were selected and the implications for the future development of policy-making in Europe. It describes the key features of the indicators and some of the ways in which they can be developed. It investigates various important issues that need to be addressed when setting quantitative targets in the context of the social inclusion process.

An important study on the measurement of social exclusion by Levitas (2006) highlights that the most important indicators to be used depend on the view of the nature of social exclusion and its causal connection to poverty. Indicators may also be found to reflect the fabric of social life, but the indicators agreed at European level are over concentrated on employment and poverty.

Chakravarty and D'Ambrosio (2006) develop an axiomatic approach to the measurement of social exclusion. At individual level, social exclusion is viewed in terms of deprivation of the person with regard to different functionings in society. At the aggregate level social exclusion is considered as a function of individual exclusion.

The study by Noya and Clarence (2008) demonstrates that the indicators of social exclusion are based not only on poverty but also on a number of other indicators such as unemployment, income, educational attainment, housing, financial exclusion and a lack of financial assets, health and mobility.

Marlier and Atkinson (2010) argue because of EU experience for a principle-based approach and explore the possible architecture of indicators of poverty and social exclusion in a multinational context. They consider the implementation of a set of indicators and their contribution to the policy process.

Labonté et al. (2011) provide a review of the literature on social exclusion. Their review of models, indicators and measures identifies nine domains that capture processes of social exclusion/inclusion. These domains are: Employment and work, income and economic resources, material resources, education and skills, health, housing, social resources, community resources and personal safety.

Silver (2015) also highlights that different histories, cultures, institutions and social structures in different places make some dimensions of social exclusion (economic, social, political) more salient and important than others.

\section{Literature on Determinants of Financial Sector Development}

The literature on the determinants of financial sector development considers a variety of macroeconomic and institutional factors, but there is no single overall view summarizing the model in a single framework. 
The financial sector is usually observed at the overall level of economic development, social and economic stability, the political and legal framework and economic opening up, while at marginal level each of these categories is difficult to isolate. They are interconnected and causality with the level of financial development is a complex phenomenon.

Literature studies the link between the activity of the financial sector and economic growth and the link between financial sector development and poverty reduction (Aghion and Hewitt, 2005; Beck et al., 2008; Perez-Moreno, 2011; Rajan and Zingales, 2003; Sehrawat and Giri, 2015). In fact, the financial sector is considered to be crucial factor in that it allocates resources and mobilizes savings and exchange of goods and services. In this sense, the financial sector facilitates economic growth directly through widening access to finance and indirectly through growth and contributing to the reduction of poverty.

Regarding the link with economic growth, there are two approaches: macroeconomic cross country studies and microeconomic studies based on sectoral and business data.

As regards the macroeconomic approach, some studies, carried out on a large number of countries, show convincingly that there is a causal link between the development of the financial system and the growth rate of the economy (Beck et al., 2000).

The microeconomic approach also confirms the close link between finance and growth within individual countries. These studies show that liberalization in the opening of bank branches is associated with higher rates of income and product growth (Jayaratne and Strahan, 1996).

Most of these studies use different indicators associated with the level of financial sector development in order to investigate the nexus between the financial system and economic growth.

The main literature presents various indicators used to measure the level of financial sector development as reported in Table 7.

Two groups of commonly used indicators can be distinguished.

The first group of indicators show the occurrence and spread of the banking sector and reflect the ratio of liquid liabilities (deposits and advances to customers and rates of interest which banks and other financial institutions have an obligation to pay) to GDP, the ratio of deposits to GDP and the presence of bank branches compared to the population or the presence of local banks (Ergungor, 2008; Ferri and Mattesini, 1997; Gertler and Rose, 1994; Goldsmith, 1969; King and Levine, 1993; McKinnon, 1973).

In particular, Goldsmith (1969) and McKinnon (1973) use the size of the formal financial intermediary sector relative to economic activity to measure financial sector development, or financial depth.

King and Levine (1993: 720) show that "one measure of financial depth equals the ratio of liquid liabilities of the financial system to GDP. Liquid liabilities consist of currency held outside the banking system plus demand and interest-bearing liabilities of banks and nonbank financial intermediaries". They construct three further indicators of financial development: the ratio of commercial bank domestic credit to the sum of commercial bank domestic credit and central bank domestic credit, which measures the relative importance of specific financial institutions, the ratio of credit on the non-financial private sectors to domestic credit and the ratio of credit issued to private sector to GDP.

Similarly Ergungor (2008: 14) uses, among others, two indicators to "measure the activity of stock markets and banks (it equals the logarithm of the value of domestic equities traded on domestic exchanges divided by GDP times the value of bank credits to the private sector divided by GDP) and measure the activity of stock markets relative to that of banks (it equals the logarithm of the value of domestic equities traded on domestic exchanges divided by the value of deposit money bank credits to the private sector)".

The 2nd group of indicators measures the amount of financial intermediation by banks and regards the relationship between domestic credit and GDP and the loans share disbursed to the private sector or credits granted to the private sector compared to GDP (Levine, 1997; 2003; Levine et al., 2002; Rajan and Zingales, 1998).

Among these variables, Rajan and Zingales (1998) consider, for example, the ratio between domestic credit plus stock market capitalization and GDP and the accounting standards in a country that reflect the potential for obtaining finance rather than the actual finance raised.

Table 7: Resume of Literature on Determinants of Financial Development

\begin{tabular}{ll}
\hline Indicators & Principal Authors \\
\hline $\begin{array}{l}\text { Ratio of liquid liabilities and GDP } \\
\text { Ratio of deposits to GDP }\end{array}$ & $\begin{array}{l}\text { Ergungor (2008; Goldsmith, 1969; McKinnon, 1973) } \\
\text { Gertler and Rose (1994; King and Levine, 1993) }\end{array}$ \\
$\begin{array}{l}\text { Presence of bank branches compared to the population or the } \\
\text { presence of local banks }\end{array}$ & Burgess and Pande (2005; Ferri and Mattesini, 1997) \\
$\begin{array}{l}\text { Relationship between domestic credit and GDP } \\
\text { Loans share disbursed to the private sector or credits granted } \\
\text { to the private sector compared to GDP }\end{array}$ & $\begin{array}{l}\text { Rajan and Zingales (1998) } \\
\text { Beck } \text { et al. (2007; Dehejia and Gatti, 2002; Honohan } \\
\text { 2004; Levine, 1997; 2003; Levine } \text { et al., 2002) }\end{array}$ \\
\hline
\end{tabular}


World Bank (2006) created the Financial Sector Development Indicators (FSDI) which go beyond size and can help assess access, efficiency and stability of financial systems.

With regard to causality between financial development and poverty reduction, various studies show that greater territorial penetration of branches and the associated higher efficiency, can lead to significant reduction in the income distribution disparity. In fact, the most important channel through which the financial sector affects poverty is improved access to financial services.

For example, Burgess and Pande (2005) show that in India, branch expansion led to the rural poverty reduction through an increase in non-agricultural activities and manufacturing activities.

As a proxy for the absence of credit constraints, Dehejia and Gatti (2002) use the ratio private credit (the value of credit by financial intermediaries to the private sector) to GDP. This variable isolates the credit granted to the private sector (compared to credit granted to governments and public companies) and captures the degree of activity of financial intermediaries. Dehejia and Gatti (2002) show that an increase in access to credit reduces the extent of child labor.

Honohan (2004) shows that an increase in the ratio of private credit issued by deposit-money banks to GDP would lead to reduction in poverty incidence. He suggests that a direct relationship between financial development and poverty reduction exists and this relationship is independent of the indirect effect through growth.

Beck et al. (2007) also use the private credit divided by GDP to measure financial development. They show that financial development leads the incomes of the poor to grow faster than average per capita GDP growth.

\section{Data and Methodology}

The present research is conducted through the collection and elaboration of data representing financial and social inclusion and financial sector development and published by different sources in the period 2016-2017.

A database on principal indicators measuring financial and social inclusion in European Countries in the period 2016-2017 is built. Data are extrapolated from several sources; Global Findex Database, IMF Financial Access Survey, ECB HFCS - Household Finance and Consumption Survey and EU-Statistics on Income and Living Conditions (EU-SILC).

Financial inclusion is determined considering three different dimensions: usage, access and barriers (Table 8). In fact, an inclusive financial system can be defined as "one that maximizes usage and access, while minimizing involuntary financial exclusion. Involuntary financial exclusion is measured by a set of barriers perceived by those individuals who do not participate in the formal financial system" (Cámara and Tuesta, 2014). Each of these dimensions is determined by several demand-side individual level indicators for usage and barrier and supply-side country level indicators for access. For example, the proportion of people having a bank account is a measure of the penetration of the banking system, while the data on the number of bank branches and the number of ATMs per 100,000 adults are a measure of the availability dimension (Sarma, 2015). Furthermore, the percentages of loans and deposit accounts in the population, the number of transactions per deposit account and the number of electronic payments show the level of usage of financial products and services (Demirgüç-Kunt et al., 2015).

Social inclusion is defined on the basis of three indicators (the at-risk-of poverty rate, people living in households with very low work intensity and severe material deprivation) which according to the European Commission (2011) reflect the multiple facets of poverty and exclusion across Europe (Table 9).

As we see in the literature, each of these dimensions represents a particular economic or familiar difficulty that is supposed to lead individuals to be not only destitute but also excluded from a series of social schemes or not able to conduct a lifestyle that is consistent with the social community.

The first indicator, i.e., at-risk-of poverty rate, indicates people whose disposable income is below $60 \%$ of the median income of their country. It is a relative measure of poverty, which takes account of all sources of monetary income.

The second indicator, i.e., share of people living in households with very low work intensity, indicates people who live in households where nobody works, but who are not necessarily living on a very low income.

The third indicator, i.e., the material deprivation rate, indicates people who cannot afford a number of necessities considered essential for a decent life.

A database on principal indicators measuring financial sector development in European Countries in the period 2016-2017 is built. Data are extrapolated from several sources; IMF - Financial Access Survey and ECB - Household Finance and Consumption Survey.

Financial sector development is determined considering the demand side and the supply side (IMF Financial Access Survey), as well as potential demand development (ECB - Household Finance and Consumption Survey) (Table 10).

Measures of financial sector development include data on volume of credit to the private sector and deposit mobilized from the private sector as a proportion of the country's GDP (Sarma, 2015), the presence of bank branches compared to the population or the presence of banks (Ergungor, 2008) and the intermediation degree, i.e., private credit to deposit (World Bank, 2006). 
Table 8: Indicators to measure financial inclusion

\begin{tabular}{|c|c|c|c|c|c|}
\hline \multicolumn{2}{|l|}{ Use } & \multicolumn{2}{|l|}{ Access } & \multicolumn{2}{|l|}{ Barriers } \\
\hline Indicator & Source & Indicator & Source & Indicator & Source \\
\hline Account & $\begin{array}{l}\text { Global Findex } \\
\text { Database }\end{array}$ & $\begin{array}{l}\text { ATMs per } \\
1,000 \mathrm{~km}^{2}\end{array}$ & $\begin{array}{l}\text { IMF, Financial } \\
\text { Access Survey }\end{array}$ & $\begin{array}{l}\text { Not applying } \\
\text { for credit }\end{array}$ & ECB HFCS \\
\hline $\begin{array}{l}\text { Borrowed from family } \\
\text { or friends }\end{array}$ & $\begin{array}{l}\text { Global Findex } \\
\text { Database }\end{array}$ & $\begin{array}{l}\text { ATM per } \\
100,000 \text { adults }\end{array}$ & $\begin{array}{l}\text { IMF, Financial } \\
\text { Access Survey }\end{array}$ & $\begin{array}{l}\text { Refused or } \\
\text { reduced credit }\end{array}$ & ECB HFCS \\
\hline $\begin{array}{l}\text { Borrowed from a financial } \\
\text { institution }\end{array}$ & $\begin{array}{l}\text { Global Findex } \\
\text { Database }\end{array}$ & $\begin{array}{l}\text { Branches per } \\
1,000 \mathrm{~km}^{2}\end{array}$ & $\begin{array}{l}\text { IMF, Financial } \\
\text { Access Survey }\end{array}$ & $\begin{array}{l}\text { Credit } \\
\text { constrained }\end{array}$ & ECB HFCS \\
\hline Saved & $\begin{array}{l}\text { Global Findex } \\
\text { Database }\end{array}$ & $\begin{array}{l}\text { Branches per } \\
100,000 \text { adults }\end{array}$ & $\begin{array}{l}\text { IMF, Financial } \\
\text { Access Survey }\end{array}$ & & \\
\hline $\begin{array}{l}\text { Main source of emergency } \\
\text { funds: Loan from a bank, } \\
\text { employer, or private lender }\end{array}$ & $\begin{array}{l}\text { Global Findex } \\
\text { Database }\end{array}$ & & & & \\
\hline Main source of emergency & Global Findex & & & & \\
\hline funds: Family or friends & Database & & & & \\
\hline $\begin{array}{l}\text { Deposit } \% \text { with a financial } \\
\text { institution account }\end{array}$ & $\begin{array}{l}\text { Global Findex } \\
\text { Database }\end{array}$ & & & & \\
\hline $\begin{array}{l}\text { No deposit and no withdrawal } \\
\text { from a financial institution } \\
\text { account }\end{array}$ & $\begin{array}{l}\text { Global Findex } \\
\text { Database }\end{array}$ & & & & \\
\hline Credit card & $\begin{array}{l}\text { Global Findex } \\
\text { Database }\end{array}$ & & & & \\
\hline Debit card & $\begin{array}{l}\text { Global Findex } \\
\text { Database }\end{array}$ & & & & \\
\hline Internet & $\begin{array}{l}\text { Global Findex } \\
\text { Database }\end{array}$ & & & & \\
\hline Account to receive wages & $\begin{array}{l}\text { Global Findex } \\
\text { Database }\end{array}$ & & & & \\
\hline $\begin{array}{l}\mathrm{N}^{\circ} \text { transactions per } \\
\text { inhabitant }\end{array}$ & ECB HFCS & & & & \\
\hline
\end{tabular}

Table 9: Indicators to measure social inclusion

\begin{tabular}{|c|c|c|c|c|c|}
\hline \multicolumn{2}{|l|}{ At-risk-of poverty rate } & \multicolumn{2}{|c|}{$\begin{array}{l}\text { People living in households } \\
\text { with very low work intensity }\end{array}$} & \multicolumn{2}{|l|}{ Material deprivation } \\
\hline Indicator & Source & Indicator & Source & Indicator & Source \\
\hline $\begin{array}{l}\text { People at risk of poverty } \\
\text { or social exclusion }\end{array}$ & EU SILC & $\begin{array}{l}\text { People living in } \\
\text { households with very } \\
\text { low work intensity }\end{array}$ & EU SILC & $\begin{array}{l}\text { Severely materially } \\
\text { deprived people }\end{array}$ & EU SILC \\
\hline $\begin{array}{l}\text { People at risk of poverty } \\
\text { after social transfers }\end{array}$ & EU SILC & & & & \\
\hline
\end{tabular}

Table 10: Indicators to measure financial sector development

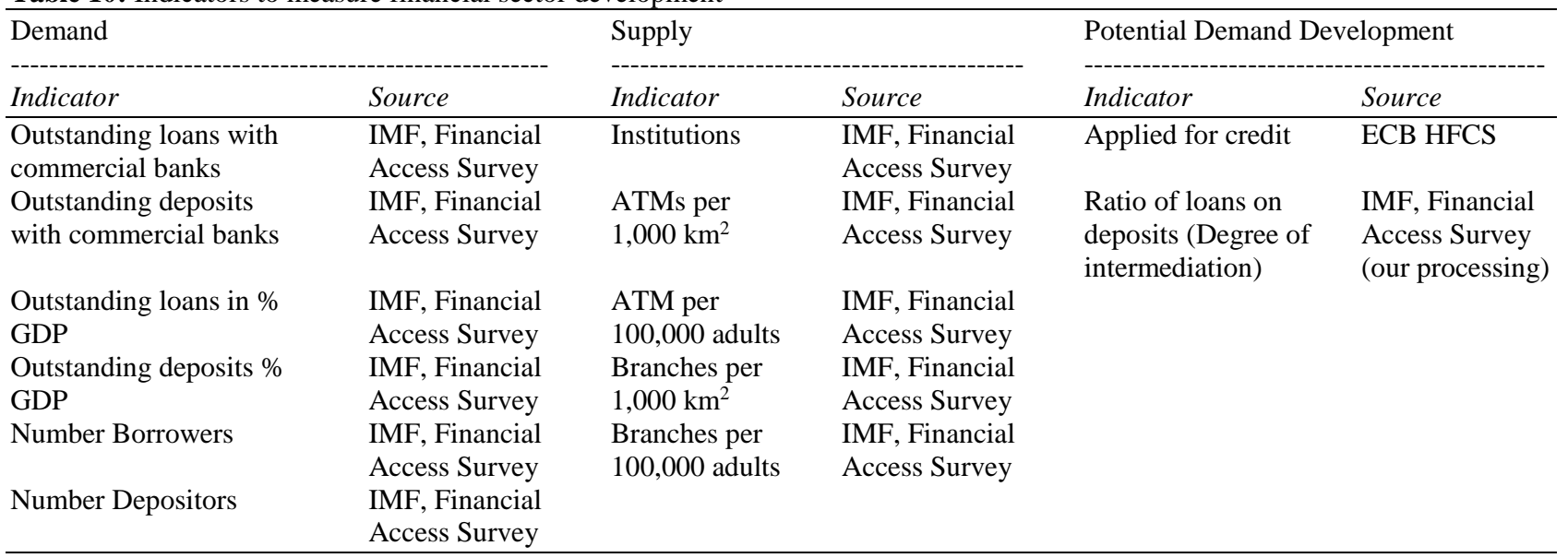


On the demand side, we thus used data on banking activity (loans and deposits, number of borrowers and depositors) and on the supply side, data on the structure of the banking system (ATM, branches, institutions). For potential growth of demand, we used data on credit from the last 3 years and the degree of intermediation expressed by the relationship between outstanding loans and outstanding deposits.

\section{Multivariate Statistical Analysis}

\section{Principal Component Analysis}

As briefly described in the previous section, an initial set of 33 indicators for the EU28 countries was identified describing the following three aspects: financial inclusion (20 indicators), social inclusion (4 indicators) and financial sector development (9 indicators). Indicators showing missing values (Not applying for credit; Refused or reduced credit; Credit constrained; Outstanding loans with commercial banks; Outstanding deposits with commercial banks; Number of Borrowers; Number of Depositors; Applied for credit) are removed from the set. Furthermore, because the number of ATMs and Branches per 100,000 adults identifies the wider level of access to the financial system, they are used as indicators only of the degree of supply development in the financial sector. The final set of indicators thus numbered 23.

The input of subsequent analysis was a $28 \times 23$ data matrix showing:

- 13 indicators of financial inclusion:

$\mathrm{X} 1=$ Account

$\mathrm{X} 2$ = Main source of emergency funds: loan from a bank, employer, or private lender

X3 = Main source of emergency funds: family or friends

$\mathrm{X} 4=\%$ Deposit with a financial institution account

$\mathrm{X} 5$ = No deposit and no withdrawal from a financial institution account

$\mathrm{X} 6$ = Borrowed from family or friends

$\mathrm{X} 7$ = Borrowed from a financial institution

$\mathrm{X} 8=$ Saved

$\mathrm{X} 9=$ Credit card

$\mathrm{X} 10=$ Debit card

$\mathrm{X} 11=$ Internet

$\mathrm{X} 12=$ Account to receive wages

$\mathrm{X} 13=\mathrm{N}^{\circ}$ transactions per inhabitant

- 4 indicators of social inclusion:

Y1 = People at risk of poverty or social exclusion

$\mathrm{Y} 2$ = People at risk of poverty after social transfers

Y3 = People living in households with very low work intensity

Y4 = Severely materially deprived people
- 6 indicators of the financial sector:

$\mathrm{Z}=$ Outstanding loans with commercial banks

$\mathrm{Z} 2$ = Outstanding deposits with commercial banks

Z3 = Ratio of loans on deposits (Intermediation Degree)

$\mathrm{Z4}=$ Branches per 100,000 adults

$\mathrm{Z5}=$ Institutions

$\mathrm{Z6}=\mathrm{ATM}$ per 100.000 adults

The correlation matrix shows high pairwise correlation between the indicators, mostly between the ones describing the same aspect. For example, the correlation between $\mathrm{X} 1$ and $\mathrm{X} 10$ is almost 0.90 and between $\mathrm{X} 3$ and $\mathrm{X} 10$ it is almost 0.80 . The correlation between $\mathrm{Y} 1$ and $\mathrm{Y} 4$ exceeds 0.90 , while the correlation between $\mathrm{Z} 1$ and $\mathrm{Z} 2$ is just below 0.90. This, together with the need to reduce the number of indicators to facilitate the interpretation of the subsequent classification, suggests it may be useful to preliminarily carry out Principal Components Analysis (PCA) in order to obtain a new set of uncorrelated variables and to reduce the dimensionality of the input features (23 initially). The first extracted components will be used as inputs to a subsequent classification tool.

The PCA was carried out separately for the 3 investigated aspects (financial inclusion, social inclusion, development of the financial system) and the results are described.

For financial inclusion (Table 11a), the first component shows a high share of total variance (about 55\%) and can be described as "Formal Financial Inclusion" as it is positively related mainly to use indicators, including the percentage of respondents who report:

- Having an account at a bank or other type of financial institution

- $\quad$ Saving or setting aside any money at a bank or other type of financial institution

- Having a debit card and credit card

- Using the internet to pay bills and

- Receiving any money from an employer directly into a financial institution account or into a card (Table 11a)

As expected, the others use indicators (such as the percentage of respondents who cite family, relatives, or friends as their main source of money and the percentage of respondents who report borrowing any money from family, relatives, or friends) are negatively related to the first component.

As regards the PCA of the second set of indictors (Table 11b), the first component explains a significant share of total variance $(69 \%)$ and can be identified as a summary measure of "Social Inclusion" as it is linked to the following indicators: people at risk of poverty or social exclusion, people at risk of poverty after social transfers, severely materially deprived people. 
Table 11: Principal component analysis

(a)

$\mathrm{X}_{1}=$ Account

Component

$\mathrm{X}_{2}=$ Main source of emergency funds: loan from a bank, employer, or private lender

1

$\mathrm{X}_{3}=$ Main source of emergency funds: family or friends

0.819

0.411

$\mathrm{X}_{4}=$ Deposit \% with a financial institution account

$-0.838$

0.635

$\mathrm{X}_{5}=$ No deposit and no withdrawal from a financial institution account

$-0.638$

$\mathrm{X}_{6}=$ Borrowed from family or friends

$-0.536$

$\mathrm{X}_{7}=$ Borrowed from a financial institution

0.681

$\mathrm{X}_{8}=$ Saved

0.918

$\mathrm{X}_{9}=$ Credit card

0.774

$\mathrm{X}_{10}=$ Debit card

0.881

$\mathrm{X}_{11}=$ Internet

0.914

$\mathrm{X}_{12}=$ Account to receive wages

0.870

$\mathrm{X}_{13}=\mathrm{N}^{\circ}$ transactions per inhabitant

0.400

Component Matrix

(b)

$\mathrm{Y}_{1}=$ People at risk of poverty or social exclusion

Component

$\mathrm{Y}_{2}=$ People at risk of poverty after social transfers

$\mathrm{Y}_{3}=$ People living in households with very low work intensity

$\mathrm{Y}_{4}=$ Severely materially deprived people

Component Matrix

(c)

$\mathrm{Z}_{1}=$ Outstanding loans with commercial banks

$\mathrm{Z}_{2}=$ Outstanding deposits with commercial banks

0.878

0.449

0.896

$\mathrm{Z}_{3}=$ Ratio of loans on deposits (Intermediation Degree)

$Z_{4}=$ Branches per 100,000 adults

$\mathrm{Z}_{5}=$ Institutions

$\mathrm{Z}_{6}=\mathrm{ATM}$

Components

Components

\begin{tabular}{ll}
1 & 2 \\
\hline 0.895 & -0.419 \\
0.875 & -0.165 \\
0.545 & -0.680 \\
0.565 & 0.455 \\
0.475 & 0.557 \\
0.544 & 0.678
\end{tabular}

Finally, with reference to the development of the financial markets (Table 11c), the first two components explain about $73 \%$ of the total variance. The first one (45\% of the variance) can be described as "Mainstream Financial Activity" and is linked to the indicators that:

- Denote the total amount of all types of outstanding loans of resident nonfinancial corporations (public and private) and households with commercial banks, calculated as: (outstanding loans with commercial banks)*100/GDP

- Denote the total amount of all types of outstanding deposits of resident nonfinancial corporations (public and private) and households with commercial banks, calculated as: (outstanding deposits with commercial banks)*100/GDP (Table 11c)

The second component (28\% of the total variance) is identified as "Potential Financial Sector Development" and is linked to intermediation degree and to the number of Institutions and ATMs of commercial banks per 100,000 adults (Table 11c).
The score matrix of the 4 principal components was the input data in order to obtain a classification of the EU28 countries:

$\mathrm{C} 1=$ Formal Financial Inclusion

$\mathrm{C} 2=$ Social Inclusion

C3 = Mainstream Financial Activity

C4 = Potential Financial Sector Development

\section{Cluster Analysis}

Cluster Analysis aims to classify a set of units into groups with the characteristics of internal cohesion (the units in the same cluster must be similar to each other) and external separation (the clusters must be as distinct as possible).

We apply a hierarchical algorithm which yields a family of partitions. Starting from a basic level yielding distinct units to a level in which all elements are classified into a single cluster (Zani and Cerioli, 2007), different agglomeration criteria (single linkage, complete linkage, average linkage, Ward's method) and 
different distance measures (city-block, Euclidean, squared Euclidean) were applied. The results are stable with regard to criteria described above. Among these, we propose the one identified by the Ward method (SPSS software).

This representation, together with the agglomeration schedule (not shown here), is helpful in choosing the partitions. We opt for the partition of the EU28 countries into the following 7 Clusters:

Cluster A (2 countries): Luxembourg, United Kingdom Cluster B (5 countries): Denmark, Estonia, Finland, Netherlands, Sweden

Cluster C (10 countries): Austria, Belgium, Czech Republic, France, Germany, Ireland, Malta, Poland, Slovak Republic, Slovenia

Cluster D (4 countries): Croatia, Italy, Portugal, Spain;

Cluster E (2 countries): Bulgaria, Romania;

Cluster F (2 countries: Cyprus, Greece;

Cluster G (3 countries): Latvia, Lithuania, Hungary

The degree of internal cohesion of a partition can be measured by the $R^{2}=B / T$ index, where the quantities $B$ and $\mathrm{T}$ are the deviance between clusters and the total deviance of the variables used in the classification. For the proposed partition, $\mathrm{R}^{2}=0.80$, which indicates a good degree of internal cohesion. For the single components (Formal financial inclusion, Social inclusion, Mainstream financial activity, Potential financial sector development) the value of the indices are respectively $0.90,0.82,0.74$ and 0.73 . In the final step of the analysis the characteristics of the clusters are described.

Table 12 lists the means of the 4 components $(\mathrm{C} 1$, $\mathrm{C} 2, \mathrm{C} 3, \mathrm{C} 4)$ corresponding to the 7 clusters of countries.

\section{Cluster Features}

\section{Cluster A "High Financial Development Regions"} (2 Countries: Luxembourg, United Kingdom)

Cluster A countries have the highest degree of formal financial inclusion (1.14), the highest degree of Mainstream Financial Activity (1.92) and the highest degree of Potential Financial Sector Development (1.06). For example, the intra-group average of the percentage of people who report having an account at a bank or other type of financial institution has a value of 0.97 against the general average of 0.91 . The group is characterized by a high use of credit cards (0.67 against a general average of 0.36$)$ and debit cards (0.90 against a general average of 0.82). Besides, there are other indexes, with an intra-group average less than the general average, represented by the percentage who cite family, relatives, or friends as their main source of money (0.16 against a general average of 0.26) and the percentage of people who report borrowing any money from family, relatives, or friends ( 0.11 against a general average of 0.14). The group is characterized by outstanding loans (110.74 against a general average of 62.68), outstanding deposits (111.62 against a general average of 61.02), ATMs (143.45 against a general average of 83.28), Institution (226.50 against a general average of 83.29) and, intermediation degree (1.00 against a general average of 0.99).

Cluster B "Financial and Social Inclusion Regions" (5 Countries: Denmark, Estonia, Finland, Netherlands, Sweden)

Cluster B countries have the highest degree of formal financial inclusion (1.12) and the lowest degree of social exclusion $(-0.76)$. In fact, the group is characterized by high use of accounts at a formal financial institution (1.00 against a general average of 0.91 ), of credit cards (0.44 against a general average of 0.36$)$ and debt cards (0.97 against a general average of 0.82). Besides, there are other indexes, with an intra-group average less than the general average, represented by the percentage who cite family, relatives, or friends as their main source of money $(0.15$ against a general average of 0.26), confirming the low use of the informal financial system. The group is characterized by few people at risk of poverty or social exclusion (\% of total population) with a value of 18.54 (against a general average of 23.77) while severely materially deprived people register a value of 2.58 (against a general average of 8.76).

Cluster C "Financial Inclusion and Limited Social Exclusion Regions" (10 Countries: Austria, Belgium, Czech Republic, France, Germany, Ireland, Malta, Poland, Slovak Republic, Slovenia)

Cluster $\mathrm{C}$ countries are characterized by formal financial inclusion (0.28) and, limited social exclusion (0.62). For example, the intra-group average of the percentage of people who report having an account at a bank or another type of financial institution has a value of 0.93 against the general average of 0.91 . Besides, there are other indexes, with an intra-group average less than the general average, represented by the percentage who cite family, relatives, or friends as their main source of money (0.19 against a general average of 0.26$)$ and the percentage of people who report borrowing any money from family, relatives, or friends ( 0.12 against a general average of 0.14 ) confirming the low use of the informal financial system. The group is characterized by limited social exclusion; in fact, in these countries the indicator "people at risk of poverty or social exclusion" (\% of total population) has a value of 19.26 (against a general average of 23.77) and the indicator "material deprivation" has a value of 5.26 (against a general average of 8.76). 


\begin{tabular}{llrrr}
\multicolumn{1}{l}{ Table 12: Cluster analysis } \\
\hline Cluster & C1 & C2 & C3 & C4 \\
\hline A & 1.1367728 & -0.4995950 & 1.9211282 & 1.0623981 \\
B & 1.1222041 & -0.7614347 & -0.4039088 & -0.8622503 \\
C & 0.2797926 & -0.6159270 & -0.4751913 & 0.4174555 \\
D & -0.3845550 & 0.6292851 & 0.9771360 & 0.6858707 \\
E & -1.8626591 & 2.2179517 & -0.4528051 & 0.4825698 \\
F & -1.6701056 & 1.1306277 & 1.2570729 & -2.1015541 \\
G & $0-.6929141$ & 0.5837780 & -0.8626264 & -0.4978711 \\
\hline
\end{tabular}

Cluster D "Limited Financial Inclusion and Social Exclusion Regions with Financial Development Potential" (4 Countries: Croatia, Italy, Portugal, Spain)

Cluster D countries show limited formal financial inclusion (-0.38) and social exclusion (0.63). However, these countries register a potential financial sector development equal to 0.68 . Specifically, the cluster is characterized by a low percentage of people who report saving or setting aside any money at a bank or other type of financial institution (0.41 against a general average of $0.44)$, by a low use of debt card (0.80 against a general average of 0.82$)$ and internet (0.41 against a general average of 0.51 ). Moreover, people at risk of poverty or social exclusion (\% of total population) register a value of 27.72 (against a general average of 23.77) and of material deprivation with a value of 9.70 (against a general average of 8.76). The cluster contains 127 institutions, against a general average of 83.29 and ATMs number 126.3126 (against a general average of 83.28).

\section{Cluster E "Financial and Social Exclusion Regions" (2 Countries: Bulgaria, Romania)}

Cluster E countries are characterized by a lower degree of formal financial inclusion (-1.86) and a higher degree of social exclusion (2.22). It is characterized by a high use source of emergency funds from family or friends $(0.52$ against a general average of 0.26 ) and borrowing from family or friends (0.22 against a general average of 0.14 ) and it also confirms the difficulty of the traditional credit access for a lot of people. The cluster is characterized by countries in which people have any difficulties accessing a formal financial system. There is very low use of accounts at a formal financial institution ( 0.65 against a general average of 0.91). The group is characterized by people at risk of poverty or social exclusion (\% of total population) with a value of 39.60 (against a general average of 23.77) and of material deprivation with a value of 27.85 (against a general average of 8.76).

Cluster F "Financial and Social Exclusion Regions with Low Financial Development Potential" (2 Countries: Cyprus, Greece)

Countries in this cluster have the lowest potential financial sector development (-2.10). They are also characterized by formal financial exclusion (-1.67) and social exclusion (1.13). These characteristics emerge in the values registered by ATMs (54.75 against a general average of 83.28), institutions (32.00 against a general average of 83.29) and intermediation degree (1.52 against a general average of 0.99). In terms of formal financial exclusion, these countries show a percentage of people who use an account equal to 0.87 (against a general average of 0.91 ), a credit card equal to 0.17 (against a general average of 0.37) and a debt card equal to 0.64 (against a general average of 0.82). The percentage of people who source emergency funds from family or friends is equal to 0.49 (against a general average of 0.26 ). The group is characterized by people at risk of poverty or social exclusion (the percentage of total population) with a value of 31.65 (against a general average of 23.77) and of material deprivation with a value of 18 (against a general average of 8.76).

Cluster G "Low Financial Development Regions", (3 Countries: Latvia, Lithuania, Hungary)

Countries in this cluster have the lowest mainstream financial activity (-0.50) and limited formal financial inclusion (-0.69). These countries also show social exclusion (0.58). They are characterized by outstanding loans (39.59 against a general average of 62.68) and outstanding deposits (39.62 against a general average of 61.02). In this group there is a low use of accounts at a formal financial institution (0.84 against a general average of 0.91$)$, credit cards (0.15 against a general average of 0.36$)$ and debit cards ( 0.70 a general average of against 0.82 ). The group is characterized by people at risk of poverty or social exclusion (percentage of total population) with a value of 28.30 (against a general average of 23.77) and of material deprivation with a value of 14.17 (against a general average of 8.76).

\section{Evaluation of the Results and Some Development Prospects}

Cluster Analysis reveals particular characteristics of countries within in particular clusters.

Cluster A is composed by 2 countries of Northern Europe (Luxembourg and United Kingdom). These two countries have the highest degree of formal financial inclusion, the highest mainstream financial activity and 
the highest potential financial sector development. In particular, Cluster A countries are characterized by several financial inclusion indicators; the use of accounts at a formal financial institution and few loans from family or friends. In fact, on one hand, a formal account allows entry into the formal financial sector, enabling the transfer of wages, remittances and government payments and also encouraging formal saving and open access to credit. On the other hand, when people have difficulties in accessing formal loans, they are forced to borrow money from family or friends. In fact, there is a high percentage of people holding accounts $(98.77 \%$ in Luxembourg and $96.37 \%$ in United Kingdom) and a lower percentage of people borrowing from family and friends $(8.02 \%$ in Luxembourg and $14.01 \%$ in United Kingdom). The use of credit cards $(69.79 \%$ in Luxembourg and $65.36 \%$ in United Kingdom), debit cards $(89.54 \%$ in Luxembourg and $91.45 \%$ in United Kingdom) is also high. In fact, the banking and financial sector plays a key role in the economy of these two countries and a wide range of products and personalized services, from traditional, classic savings product, to sophisticated solutions for creating and supplying wealth are on offer. In United Kingdom the amount of outstanding loans from commercial banks and the amount of outstanding deposits compared to GDP are both high and equal to respectively 125.64 and 133.18 . Values are slightly lower for Luxembourg. These 2 countries have a significant presence of institutions located throughout the country with the highest value registered in the United Kingdom (312 institutions) and a slightly lower value recorded in Luxembourg (141 institutions). The intermediation degree is equal to 0.94 in the United Kingdom and slightly higher in Luxembourg and equal to 1.06.

Cluster B contains 5 countries of Northern Europe (Denmark, Estonia, Finland, Sweden, Netherland). These countries show the highest degree of formal financial inclusion (like Cluster A) and the lowest degree of social exclusion. Among the indicators of financial inclusion, for example, the percentage of respondents who report having an account at a bank or other type of financial institution is the highest among the EU28 countries and equal to almost $100 \%$ in Denmark, Finland, Sweden and Netherlands and equal to $97.99 \%$ in Estonia. In Cluster $\mathrm{B}$, the percentage of respondents who report saving or setting aside any money at a bank or another type of financial institution is the highest in Sweden (75.43\%) and the lowest in Estonia (46.93\%). Furthermore, in Netherlands only $8 \%$ of families in case of emergency consider as main source of emergency funds relatives and friends. The percentages who cite families, relatives, or friends as their main source of the money in Denmark, Finland and Sweden are slightly higher at 14\%, 11\% and $12 \%$ respectively. The value is higher in Estonia and equal to $29 \%$. These data are confirmed by the fact that in Denmark, the banking sector is the largest credit provider. Denmark shows one of the highest degrees of concentration and is among the largest in Europe, measured as a ratio of GDP. In Estonia there are signs that the economy has recently been recovering and there is a level of financial inclusion comparable with Western Europe. Denmark, Finland and Netherlands present the lowest values of people at risk of poverty, almost equal to $16 \%$. The percentage of people at risk of poverty increases in Estonia, where it is equal to $24.40 \%$.

Cluster C contains 2 countries of Northern Europe (Belgium and Ireland), 4 countries of Eastern Europe (Slovakia, Slovenia, Czech Republic and Poland), 3 countries of Central Europe (Austria, France and Germany) and one country of Southern Europe (Malta). It comprises countries with financial inclusion and limited social exclusion, characterized by the highest percentages of people holding an account at a formal financial institution, as in Germany $(99.14 \%)$ and by the lowest value of borrowing from family or friends as observed in Malta (8\%). Furthermore, with regard to social exclusion, six Cluster $\mathrm{C}$ countries have the lowest level of people at risk of poverty and social exclusion; these countries are Czech Republic (13.30), Austria (18.00) and Slovak Republic (18.10). An interesting aspect is that Cluster $\mathrm{C}$ includes countries such as Slovakia, Slovenia, Czech Republic, Poland and Malta that in the second half of the last century lived through particular political and economic conditions. Other Cluster $\mathrm{C}$ countries shared similar political and economic values and ideologies in spite of country differences. For example, different indicators make Malta similar to the other countries: the intermediation degree is similar in Malta $(0.61 \%)$ and Germany $(0.74 \%)$, deprived people account for $4.40 \%$ both in Malta and in France and the loans from relatives and friends are about $8 \%$ in Malta and in Belgium, France and Germany.

Cluster D contains 1 country of Eastern Europe (Croatia) and 3 countries of Southern Europe (Italy, Portugal and Spain). This Cluster shows limited financial inclusion and the presence of social exclusion. An indepth study of the characteristics of the individual countries shows, for example, that in Croatia $43.43 \%$ of the population turn to families for emergency resources, while only $6.13 \%$ of the population approach banks. Furthermore, in Portugal only $9 \%$ of people report borrowing any money from a bank or another type of financial institution and this despite the fact that $92 \%$ report having an account at a bank or other type of financial institution and $87 \%$ of the population report making one or more deposits in their account per month. A similar situation is also recorded in Italy and Spain. People at risk of poverty in these countries vary between $25.10 \%$ in Portugal and $30 \%$ in Italy. In addition, these countries show potential for financial development as they have a high number of institutions and ATMs. In 
Italy there are in fact 264 institutions, a number lower only than that in United Kingdom and France, while in Croatia there are 127.93 ATMs, a number lower only than that recorded in Luxembourg.

Cluster E contains 2 countries both of Eastern Europe (Bulgaria and Romania). These countries show the lowest degree of formal financial inclusion and the highest degree of social exclusion. Among the indicators of financial inclusion, for example, the percentage of respondents who report having an account at a bank or other type of financial institution is the lowest in EU28, at $58 \%$ in Romania and $72 \%$ in Bulgaria. The percentage of respondents who report saving or setting aside any money at a bank or other type of financial institution is very low in Romania (14\%) and slightly higher in Bulgaria (28\%). In Romania, household savings are negative (gross expenditures exceed disposable income). Furthermore, in these two countries, people look for emergency funding from relatives and friends, rather than from banks or other financial institutions; the percentage who cite families, relatives, or friends as their main source of money in Bulgaria is $47 \%$ and in Romania $58 \%$. This situation is confirmed by the fact that "Bulgaria has one of the lowest proportions of banked citizens in the CEE region - 63\%, 16 percentage points lower than average for CEE countries. Bulgarians have one of the lowest trusts in banks ratios in the CEE region at just $34 \%$. As many banks operating in Bulgaria are Greek-owned (with a market share around $20 \%$ in 2015), their potential divestment may pose supervisory challenges and result in substantial changes to the structure of the banking sector" (Deloitte, 2018). Bulgaria and Romania present the highest percentages of people at risk of poverty, 40.40 and 38.80 respectively.

In Cluster F 2 countries of Southern Europe are present (Cyprus and Greece). These countries show the lowest potential financial sector development. In Cyprus, commercial bank there are 50.07 ATMs per 100,000 adults and the number of institutions is 36 . In Greece, there is a higher rate of commercial bank ATMs per 100,000 (59.44) and the number of institutions is 28 . The intermediation degree for these two countries is high; $1.54 \%$ in Cyprus and $1.50 \%$ in Greece.

This situation implies the presence in these two countries of formal financial exclusion and social exclusion. In Greece, for example, around $63 \%$ of the population resort to relatives and friends for emergency financial resources and only $2 \%$ of the population request loans from banks or other types of financial institutions. Cyprus shows similar values. In addition, the percentage of people at risk of poverty is $27.70 \%$ in Cyprus and $35.60 \%$ in Greece.

Cluster G contains 3 countries of Eastern Europe (Latvia, Lithuania and Hungary). These countries show the lowest mainstream financial activity and very limited formal financial inclusion (-0.69). They also present social exclusion. They present low values in terms of total amount of all types of outstanding loans of resident nonfinancial corporations and households with commercial banks, as well as total amount of all types of outstanding deposits of resident nonfinancial corporations and households with commercial banks compared to GDP. Hungary in particular registers very low values of outstanding loans and outstanding deposits, equal respectively to $30.51 \%$ and $36.51 \%$. In fact, in Hungary, trust in the banking sector is very low and only $27 \%$ of the population say they have confidence in it (Deloitte, 2018). In Latvia almost $93 \%$ of people use an account at a formal financial institution, while in Hungary the percentage is $75 \%$. Furthermore, here too emergency funds are mainly sourced from families rather than financial institutions. Finally, the percentage of people at risk of poverty is $26.30 \%$ in Hungary and $30.10 \%$ in Lithuania.

\section{Conclusions}

The analysis of the phenomena of financial inclusion and social inclusion together with the development of the financial sector offers useful food for thought.

First, in some EU28 countries (Bulgaria, Cyprus, Greece and Romania) there are still people excluded from the formal financial system or who resort to relatives and friends for credit. These are people who may be exposed to unforeseen events, such as the temporary unavailability of income, or who are unable to access banking services often for relational reasons, often including low education levels, geographical dislocation in areas with economic and financial difficulties, etc. In these countries these issues are linked to social exclusion.

Secondly, it is clear that the EU28 countries in which there is a high degree of potential financial sector development (Luxembourg and United Kingdom) are also those showing the highest levels of financial and social inclusion.

The analysis could usefully be extended by further study. The identification of geographical areas with different characteristics should be useful for design and planning of interventions aimed at financial and social inclusion, access to credit and development of the financial system, in several countries investigated. Given the numerous initiatives aimed at harmonization and improvement of European policies, a significant role could be played by microcredit

\section{Acknowledgement}

Research project funded by EIB University Research Sponsorship (Eiburs) - European Investment Bank Institute. Any errors remain those of the authors. The findings, interpretations and conclusions presented in this article are entirely those of the authors and should 
not be attributed in any manner to the European Investment Bank.

\section{Author's Contributions}

The paper is the fruit of the joint work of the authors, however Domenica Federico mainly contributed to Sections "Literature on Definitions and Measures: Social inclusion" and "Literature on Determinants of Financial Sector Development"; Maria Adele Milioli to Section "Multivariate Statistical Analysis"; Antonella Notte to Sections "Literature on Definitions and Measures: Financial inclusion" and "Data and Methodology"; Lucia Poletti to Sections "Introduction", "Evaluation of the Results and Some Development Prospects" and "Conclusions".

\section{Ethics}

This article is original and contains unpublished material. The corresponding author confirms that all of the other authors have read and approved the manuscript and no ethical issues involved.

\section{References}

Aghion, P. and P. Hewitt, 2005. Appropriate growth policy: A unifying framework. Joseph Schumpeter Lecture J. Eur. Economic Assoc., 4: 269-314. DOI: 10.1162/jeea.2006.4.2-3.269

Amado, A., R.J. Novak Stancliffe, M. McCarren and P. McCallion, 2013. Social inclusion and community participation of individuals with intellectual/developmental disabilities. Intellectual Dev. Disabilities, 51: 360-75. DOI: 10.1352/1934-9556-51.5.360

Amidžić, G., A. Massara and A. Mialou, 2014. Assessing countries' financial inclusion standing - a new composite index. Working Paper International Monetary Fund.

Ampudia, M. and M. Ehrmann, 2017. Financial inclusion: What's it worth. Working Paper Series European Central Bank.

Atkinson, A.B., 1998. Poverty in Europe. 1st Edn., Blackwell, Oxford, ISBN-10: 0631210296, pp: 200.

Atkinson, T., B. Cantillon, E. Marlier and B. Nolan, 2002. Social Indicators: The EU and Social Inclusion. 1st Edn., Oxford University Press, Oxford, ISBN-10: 019153093X, pp: 256.

Atkinson, T., E. Marlier and B. Nolan, 2004. Indicators and targets for social inclusion in the European union. J. Common Market Study, 42: 47-75. DOI: $10.1111 /$ j.0021-9886.2004.00476.x

Atkison, A.B. and E. Marlier, 2010. Analysing and Measuring Social Inclusion in a Global Context. 1st Edn., United Nations Publications, ISBN-10: 9211302862, pp: 68.
Beauvais, C. and J. Jenson, 2002. Social cohesion: Updating the state of the research. Canadian Policy Research Networks Discussion Paper.

Beck, T., A. Demirgüç-Kunt and R. Levine, 2007. Finance, inequality and the poor. J. Economic Growth, 12: 27-49. DOI: 10.1007/s10887-007-9010-6

Beck, T., A. Demirgüç-Kunt, L. Laeven and R. Levine, 2008. Finance, firm size and growth. J. Money Credit, Bank., 40: 1379-405. DOI: $10.1111 / \mathrm{j} .1538-4616.2008 .00164 . \mathrm{x}$

Beck, T., N. Loayza and R. Levine, 2000. Financial intermediation and growth: Causality and causes. J. Monetary Econom., 46: 31-77. DOI: $10.1016 /$ S0304-3932(00)00017-9

Berger, P., 1998. The Limits of Social Cohesion: Conflict and Mediation Pluralist Societies. 1st Edn., Westview Press, ISBN-10: 0813334012, pp: 369.

Bernard, P., 1999. Social cohesion: Critique d'un quasiconcept. Lien Social et Politiques RIAC, 41: 47-59.

Bossert, W., C. D'Ambrosio and V. Peragine, 2007. Deprivation and social exclusion. Economica, 74: 777-803. DOI: 10.1111/j.1468-0335.2006.00572.x

Brunkhorst, H. and J. Flynn, 2005. Solidarity: From Civic Friendship to a Global Legal Community. 1st Edn., The MIT Press, ISBN-10: 0262025825, pp: 336.

Burchardt, T., J. Le Grand and D. Piachaud, 1999. Social exclusion in Britain 1991-1995. Soc. Policy Admin., 33: 227-244. DOI: 10.1111/1467-9515.00148

Burgess, R. and R. Pande, 2005. Do rural banks matter evidence from the Indian social banking experiment. Am. Economic Rev., 95: 780-95. DOI: $10.1257 / 0002828054201242$

Cámara, N. and D. Tuesta, 2014. David Measuring Financial Inclusion: A multidimensional index. Working Paper BBVA Research.

Carbo, S., E.P. Gardener and P. Molyneux, 2005. Financial Exclusion. 1st Edn., Palgrave Macmillan, London, ISBN-13: 978-1-349-54245-1.

Chakravarty S. and C. D'Ambrosio, 2006. The measurement of social exclusion. Rev. Income Wealth Series, 52: 377-98. DOI: 10.1111/j.1475-4991.2006.00195.x

Chakravarty, S. and R. Pal, 2010. Measuring financial inclusion: An axiomatic approach. Working Paper Indira Gandhi Institute Development Research.

Clement, T. and C. Bigby, 2009. Breaking out of a distinct social space: Reflection on supporting community participation for people with severe and profound intellectual disability. J. Applied Res. Intellectual Disabilities, 22: 264-75. DOI: $10.1111 /$ j.1468-3148.2008.00458.x

Cobigo, V., H. Ouellette-Kuntz, R. Lysaght and L. Martin, 2012. Shifting our conceptualization of social inclusion. Stigma Res. Act., 2: 75-84. 
Conroy, J., 2005. APEC and financial exclusion: Missed opportunities for collective action. Asia-Pacific Dev. J. 12: 53-79. DOI: 10.18356/339ee7fc-en

Daly, M. and H. Silver, 2008. Social exclusion and social capital. Theory Society, 37: 537-66. DOI: $10.1007 / \mathrm{s} 11186-008-9062-4$

Daly, M., 2006. Social exclusion as concept and policy template in the European union. Working Paper Series Center European Studies.

Deakin, N., N. Thomas and A. Davis, 1995. Public Welfare Services and Social Exclusion: The Development of Consumer-Oriented Initiatives in the European Union. 1st Edn., European Foundation for the Improvement of Living and Working Conditions, ISBN-10: 928274907X, pp: 150.

Dehejia, R. and R. Gatti, 2002. Child labor: The role of income variability and access to credit across countries. Working Paper, NBER (9018).

Deloitte, 2018. Fintech in CEE. Department for International Trade.

Demirgüç-Kunt, A., L. Klapper, D. Singer and P. Van Oudheusden, 2015. The global findex database 2014 measuring financial inclusion around the world. Policy Research Working Paper, World Bank (7255).

Dugarova, E. and T. Lavers, 2014. Social inclusion and the post-2015 sustainable development agenda. Paper prepared for the UNITAR's Briefing for UN Delegates on Post-2015 Development Agenda: Social Inclusion: UNRISD, Geneva.

Dugarova, E., 2015. Social inclusion, poverty eradication and the 2030 agenda for sustainable development. Working Paper, UNRISD (14).

Duggan, C. and C. Linehan, 2013. The role of natural supports in promoting independent living for people with disabilities: A review of existing literature. Brit. J. Learn. Disabilities, 41: 199-207. DOI: $10.1111 /$ bld. 12040

Ergungor, E., 2008. Financial system structure and economic growth: Structure matters. Working Papers, Federal Reserve Bank of Cleveland (3/5).

European Commission, 2008. Financial services provision and prevention of financial exclusion. Bruxelles.

European Commission, 2011. The social dimension of the Europe 2020 strategy. A report of the Social Protection Committee, Bruxelles.

European Union, 2004. Joint report on social inclusion. Directorate General for Employment and Social Affairs.

Eurostat, 2013. The measurement of poverty and social inclusion in the EU: Achievements and further improvements. Paper at the Seminar The way $\mathrm{zd}$ in Poverty Measurement United Nations Economic Commission for Europe.
Ferri, G. and F. Mattesini, 1997. Finance human capital and infrastructure: An Empirical investigation on postwar Italian growth. Working Paper, Bank of Italy, (321).

Finaccess, 2016. FinAccess household survey. Central Bank of Kenya.

Frazer, H. and E. Marlier, 2013. Assessment of progress towards the Europe 2020 social inclusion objectives: Main findings and suggestions on the way forward - a study of national policies. European Commission, Bruxelles.

Gertler, M. and A. Rose, 1994. Finance Public Policy and Growth in Financial Reform: Theory and Experience. Caprio, G.I. and J.A. Atiljas (Eds.), Hanson Cambridge University Press, New York, pp: 13-45.

Ghosh, J., 2010. Poverty reduction in china and India: Policy implications of recent trends. Working Paper, DESA (92).

Gloukoviezoff, G., 2004. The caisse d'epargne and households financial exclusion. which actions should be taken and what are the prospects. Proceedings of the Access to Finance Conference, (AFC' 04), Brussels.

Goldsmith, R.W., 1969. Financial structure and development. Yale University Press, New Haven.

Goodin, R.E., 1996. Inclusion and exclusion. Eur. J. Sociol., 37: 343-71. DOI: $10.1017 / \mathrm{S} 0003975600007219$

Gortsos, C.V., 2016. Financial inclusion: An overview of its various dimensions and the initiatives to enhance its current level. Working Papers ECEFIL 15.

Hall, E., 2010. Spaces of social inclusion and belonging for people with intellectual disabilities, J. Intellectual Disability Res., 54: 48-57. DOI: $10.1111 /$ j.1365-2788.2009.01237.x

Hall, S.A., 2009. The social inclusion of people with disabilities: A qualitative meta-analysis. J. Ethnographic Qualitative Res., 3: 162-73.

Hanning A. and S. Jansen, 2010, Financial inclusion and financial stability: Current policy issues. ADBI Working Paper Series.

Hickey, S. and A. du Toit, 2007. Adverse incorporation social exclusion and chronic poverty. Working Paper, Chronic Poverty Research Centre, University of Manchester, (81).

Honohan, P., 2004. Financial Development, Growth and Poverty: How Close are the Links? In: Financial Development and Economic Growth, Goodhard, E.C. (Eds.) Palgrave, London, ISBN-13: 978-0-230-37427-0 pp: 1-37.

Honohan, P., 2008. Cross-country variation in household access to financial services. J. Bank. Finance, 32: 2493-500. DOI: 10.1016/j.jbankfin.2008.05.004

Hospes, O. and J. Clancy, 2011. Unpacking the Discourse of Social Inclusion in Value Chains. In: Value Chains, Inclusion and Endogenous Development: Contrasting Theories and Realities, Helmsing, A.H.J. and S. Vellema (Eds.), Routledge, London. 
Jayaratne, J. and P.E. Strahan, 1996. The finance-growth nexus: Evidence from bank branch deregulation. Quarterly J. Econom., 111: 639-70.

DOI: $10.2307 / 2946668$

Johnson, S. and M. Nino-Zarazua, 2011. Financial access and exclusion in Kenya and Uganda. J. Dev. Stud., 47: 475-96.

DOI: $10.1080 / 00220388.2010 .492857$

Kempson, E. and C. Whyley, 1999. Kept out or opted out? Understanding and combating financial exclusion. Policy Press, Bristol.

Kempson, E. and S. Collard, 2012. Developing a vision for financial inclusion. Friends Provident Foundation, London.

Kempson, E., C. Whyley, J. Caskey and S. Collard, 2000. In or out financial exclusion: A literature and research review. Financial Services Authority, London.

King, R.G. and R. Levine, 1993. Finance and growth: Schumpeter might be right. Quarterly J. Econom., 108: 717-38. DOI: $10.2307 / 2118406$

Korynski, P., 2013. Calculation of the composite Index of Financial Inclusion (IFI): A methodological note. Microfinance Centre (MFC).

Kumar Kuri, P. and A. Laha, 2011. Determinants of financial inclusion: A study of some selected districts of west Bengal, India. ICSSR Major Research.

Kumar, N., 2013. Financial inclusion and its determinants: Evidence from India. J. Financial Economic Policy, 5: 4-19. DOI: $10.1108 / 17576381311317754$

Kymlicka, W., 2010. The rise and fall of multiculturalism new debates on inclusion and accommodation in diverse societies. Int. Soc. Sci. J., 61: 97-112. DOI: 10.1111/j.1468-2451.2010.01750.x

Labonté, R., A. Hadi and X.E. Kauffmann, 2011. Indicators of social exclusion and inclusion: A critical and comparative analysis of the literature. Working Papers, EiExchange.

Levine, R., 1997. Financial development and economic growth: Views and agenda. J. Economic Literature, 35: 688-726.

Levine, R., 2003. More on finance and growth: More finance more growth. Federal Reserve Bank St. Louis Rev., 85: 31-46. DOI: 10.20955/r.85.31-46

Levine, R., N. Loayza and T. Beck, 2002. Financial intermediation and growth: Causality and causes. Central Bank. Anal. Economic Policies Book Series, 3: 31-84.

Levitas, R., 2006. The Concept and Measurement of Social Exclusion. In: Poverty and Social Exclusion in Britain, Pantazis, C., D. Gordon and R. Levitas (Eds.), Policy Press, Bristol.

Leyshon, A. and N. Thrift, 1995. Geographies of financial exclusion: Financial abandonment in Britain and the United States. Tran. Institute Brit. Geographers, 3: 312-41. DOI: 10.2307/622654
Marlier, E. and A.B. Atkinson, 2010. Indicators of poverty and social exclusion in a global context. J. Policy Anal. Manage., 29: 285-304. DOI: 10.1002/pam.20492

McKinnon, R.I., 1973. Money and capital in economic development. J. Int. Econom., 4: 223-24. DOI: $10.2307 / 40201473$

Mehrotra, N., V. Puhazhendhi, G. Nair and B.B. Sahoo, 2009. Financial inclusion - an Overview. Occasional Paper Department of Economic Analysis and Research National Bank for Agriculture and Rural Development (NABARD).

Mohan, R., 2006. Economic growth financial deepening and financial inclusion. Address at the Annual Bankers' Conference Hyderabad.

Muffels, R. and D. Fouarge, 2001. Social Exclusion and Poverty: Definition, Public Debate and Empirical Evidence in the Netherlands. In: Social Exclusion and European Policy, Mayes, D.G., J. Berghman and R. Salais (Eds.), Edward Elgar, Northampton, MA.

Noya, A. and E. Clarence, 2008. Improving social inclusion at the local level through the social economy. OECD LEED Programme.

OECD, 2013. Financial literacy and inclusion. Results of OECD/INFE survey across countries and by Gender. Organisation for Economic Co-Operation and Development, Paris.

Pantazis, C., D. Gordon and R. Levitas, 2006. Poverty and social exclusion in Britain: The millennium survey. Policy Press, Bristol.

Perez-Moreno, S., 2011. Financial development and poverty in developing countries: A causal analysis. Empirical Econom., 41: 57-80. DOI: $10.1007 / \mathrm{s} 00181-010-0392-5$

Power, A., 2013. Making pace for belonging: Critical reflections on the implementation of personalized adult social care under the veil of meaning full inclusion. Soc. Sci. Med., 88: 68-75.

DOI: 10.1016/j.socscimed.2013.04.008

Putnam, R.D., 2007. E Pluribus Unum: Diversity and community in the twenty-first century-the 2006 Johan Skytte Prize lecture. Scandinavian Political Studies, 30: 137-74. DOI: 10.1111/j.1467-9477.2007.00176.x

Quinn, G. and S. Doyle, 2012. Getting a life-living independently and being included in the community: A legal study of the current use and future potential of the EU structural funds to contribute to the achievement of Article 19 of the united nations convention on the rights of persons with disabilities. Report to the Office of the United Nations High Commissioner for Human Rights, Regional Office for Europe. 
Rajan, R.G. and L. Zingales, 1998. Financial dependence and growth. Am. Economic Rev., 88: 559-86.

Rajan, R.G. and L. Zingales, 2003. Saving Capitalism From Capitalists. 1st Edn., Crown Business, ISBN-13: 0609610708, pp: 369.

Rojas-Suarez, L., 2010. Access to financial services in emerging powers: Facts, Obstacles and Policy Implications. OECD Global Development Background Papers.

Sarma, M., 2008. Index of financial inclusion. ICRIER Working Paper 215.

Sarma, M., 2012. Index of Financial Inclusion. A measure of financial sector inclusiveness. Working Papers, Money, Finance, Trade and Development 7.

Sarma, M., 2015. Measuring financial inclusion. Economics Bulletin.

Sathiyan, S. and P.K. Panda, 2016. Financial inclusion in India: An analysis of pattern and determinants. Indian J. Finance, 10: 41-53.

DOI: $10.17010 / \mathrm{ijf} / 2016 / \mathrm{v} 10 \mathrm{i} 4 / 90799$

Sehrawat, M. and A.K. Giri, 2015. Financial development, poverty and rural-urban income inequality: Evidence from South Asian countries. Quality Quantity, 50: 1-14. DOI: $10.1007 / \mathrm{s} 11135-015-0164-6$

Silver, H., 1994. Social exclusion and social solidarity: 3 paradigms. Int. Labour Rev., 133: 531-78.

Silver, H., 2015. The contexts of social inclusion. Working Paper, DESA.

Simplican, S.C., G. Leader, J. Kosciulek and M. Leahy, 2015. Defining social inclusion of people with intellectual and developmental disabilities: An ecological model of social networks and community participation. Res. Dev. Disabilities, 38: 18-29. DOI: 10.1016/j.ridd.2014.10.008

Sinclair, S.P., 2001. Financial exclusion: An introductory survey. Report of centre for research in socially inclusive services. Heriot-Watt University, Edinburgh.

Singh, K. and S. Kondan, 2012. Financial inclusion development and its determinants: An empirical evidence of Indian states. Asian Economic Rev., 53: 115-34.

Toye, M. and J. Infanti, 2004. Social inclusion and community economic development literature review. Pan-Canadian Community Development Learning Network Project Framework.
Tsakloglou, P. and F. Papadopoulos, 2002. Identifying Population Groups at High Risk of Social Exclusion. In: Social Exclusion in European Welfare States, Muffels, R., P. Tsakloglou and D. Mayes (Eds.), Edward Elgar, Cheltenham.

UNCDF, 2006. Building Inclusive Financial Sectors for Development. 1st Edn., United Nations Publications, ISBN-10: 9212042511, pp: 182.

United Nations, 1995. World summit for social development. Report A/CONF.166/9, Copenhagen.

United Nations, 2010. Analysing and measuring social inclusion in a global context. Department of Economic and Social Affairs, New York.

Verdonschot, M.M.L., L.P. de Witte, E. Reichrath, W.H.E. Buntinx and L.N.G. Curfs, 2009. Impact of environmental factors on community participation of persons with an intellectual disability: A systematic review. J. Intellectual Disability Res., 53: 54-64. DOI: 10.1111/j.1365-2788.2008.01128.x

Walker, H.M., C. Calkins, M.L. Wehmeyer, L. Walker and A. Bacon et al., 2011. A social ecological approach to promote self-determination. Exceptionality: A Special Educ. J., 19: 6-18. DOI 10.1080/09362835.2011.537220

Woodward, A. and M. Kohli, 2001. European Societies: Inclusions/Exclusions. In: Inclusions and Exclusions in European society, Woodward, A. and M. Kohli (Eds.), Routledge, London.

World Bank, 2005. Indicators of financial accesshousehold level surveys. Washington, DC.

World Bank, 2006. Measuring banking sector development. Washington, DC.

World Bank, 2007. Social exclusion and the Eus social inclusion agenda. Washington, DC.

World Bank, 2013. Inclusion matters: The foundation for shared prosperity. Washington, DC.

World Bank, 2014. Global financial development report 2014: Financial inclusion. Washington, DC.

Zani, S. and A. Cerioli, 2007. Analisi dei dati e data mining per le decisioni aziendali. Giuffrè Editore, Milan. 